\title{
УДК 37.012:929(045)
}

\section{SCIENCE OF PEDAGOGY: WAYS OF RESEARCH OF PERSONNELS ПЕДАГОГІЧНА БІОГРАФІСТИКА: ШЛЯХИ ДОСЛІДЖЕННЯ ПЕРСОНАЛІЙ}

Iryna Rozman / Ірина Розман

Ph. D. (Pedagogy) / к.пед.н., доцент, ORCID ID: https://orcid.org/0000-0002-4951-0074 Mukachevo State University, Uzhhorod, 26, $89600 /$ Мукачівський державний університет, Ужсгородська, 26, 89600

\begin{abstract}
The article considers the ways of research of pedagogical personalities. Particular attention is paid to highlighting the importance of methods of studying the experience of the scientist. It is noted that for a detailed study of pedagogical personality it is necessary to know the features of the life historical period of the scientist. The influence of biography science on the educational process in Ukraine is noted.
\end{abstract}

Key words: pedagogical biography, diachronic method, subject of research.

Introduction. In the process of a large array of scientific, educational, popular science, reference literature on the life of teachers in the Ukrainian historical and pedagogical science formed a separate research and personalized area, which borders on many subjects - the science of biography. It is closely related to other branches of pedagogy (history of pedagogy, didactics, theory and practice of education, pedagogical comparative studies, social pedagogy).

At the beginning of the XXI century, special attention is paid to pedagogical theory, which contributes to the education of future teachers. Nothing is built without a fundamental foundation and laid foundations. Therefore, we can safely say that the substantive basis of the technology of personalized approach is the pedagogical personality [8, p. 7].

The main material. In this regard, there are new disciplines, new technologies for their study, new methods of mastering the program material. Students study "School Studies", special courses "History of National Pedagogical Thought", "Pedagogical Personalism", "Pedagogical Biography". These subjects provide new opportunities to study pedagogical personalities. It is necessary to study the creativity of the teacher in his interaction with various aspects of life. This approach to teaching shows the teacher not only as an individual creator, but also as a representative of pedagogical thought of a particular historical era [1, p. 82].

The main approach to acquainting with the teacher's personality is biographical. This is a way of processing the analysis of sources, in which the biography is a determining factor in his work. He also demonstrates the era in which the scientist lived and worked. Biographical approach helps to find the reasons for the emergence and development of pedagogical ideas [6, p. 14].

Refusal to idealize the image during the analysis and description of scientific and pedagogical views of the individual helps to better understand it. Hermeneutics is the "art of understanding", commenting, explaining texts. We see the personality through a historical prism.

The paradigmatic approach makes it possible to consider the logic of the development of the ideas of a particular teacher from the standpoint of science itself. 
The science of biography helps to objectively understand the internal dynamics of personal development. The life of pedagogical personalities differs depending on the historical in which they live and work [2, p. 37]. We use the diachronic method of studying the pedagogical personality. Such a study of biography can be represented as a vertical line that shows the life dates we need.

In the study of pedagogical personality, it is advisable to combine these approaches, which makes it possible to more fully assess the impact of pedagogical ideas of the scientist on the development of modern pedagogical science.

For pedagogical science, the turn of the XX and XXI centuries was marked by activity in the educational process. There is a need to identify the main moments of the teacher's life. The main work is shown on the personal qualities of man. They provide an opportunity to express very important characteristics for life. Identify life plans, achievements in pedagogical work.

The development of pedagogical theory and practice and the educational process is impossible without the creative use of pedagogical ideas of teachers of the past. Well-known educators of the past help to objectively assess the historical reality.

Educational activities should be considered only in relation to the activities of a particular individual or historical figure. She has already made a contribution to the development of education and pedagogical thought of a certain historical period [1, p. 82].

Personification is one of the most important approaches to the study of the spiritual and moral culture of the individual. Personification is a necessity of pedagogical action with persons, ideals, samples, historical and pedagogical processes.

But the deep permanent crisis, in which Ukraine has been for almost three decades and which has become systemic, requires finding ways and effective means to successfully overcome it through the study of new approaches to teaching staff [7].

As for the values of education, it seems appropriate to cite the opinion of GM Kodzhaspirova, who emphasizes that axiology "in modern pedagogy acts as its methodological basis, which determines the system of pedagogical views, which is based on understanding and affirming the value of human life, education and training , pedagogical activity and education "[5].

Much of the creative biographies for the first time become the subject of scientific research. Many scholars today turn to the study of issues related to the origin, formation and development of domestic pedagogical thought. Ukrainian researchers study the heritage of outstanding teachers: N. Gupan, N. Demyanenko, N. Dichek, T. Levchenko, O. Lyubar, V. Maiboroda, L. Medvid, O. Melnychuk, V. Mosiyashenko, O. Padalka, N. Pobirchenko , S. Sysoeva, M. Stelmakhovych, B. Stuparyk, O. Sukhomlynska, T. Usatenko, D. Fedorenko.

Conclusions. Thus, the study of personalities influencing the educational process in Ukraine is a component of the development of modern science and is considered in the dynamics and time sequence. To do this, it is necessary to get acquainted with the main periods of life and creative path of individuals. It is necessary to analyze the influence of political, ideological and philosophical currents on the formation of the worldview of the teacher. 
The basis for the study of property is the legal framework, documentary information, government documents, laws, regulations, textbooks, scientific articles. There is a sociological selection of material, its classification, periodization, definition of the categorical apparatus, formulation of conclusions and proposals. Further research provides an opportunity to update the experience of personalities and prospects for the use of historical and pedagogical heritage in modern pedagogical science.

\section{Reference}

1. Adamenko O.O. (2011), Technology of personalized approach as a means of improving the training of future teachers. URL: http: // www.irbis-nbuv.gov.ua/cgi (access date: 18.01.2018).

2. Boguslavsky M. (1999), The structure of modern historical and pedagogical knowledge // The path of education. № 1. P. 37 - 40.

3. Vakhovsky L. (2005), Research methodology of historical and pedagogical process: problem statement // The way of education. . № 4. P. 7 - 9.

4. Dichek N.P. (2001), Biographical method as a tool for studying the national history of pedagogy // The path of education. № 4. S. 15 -19.

5. Kodzhaspirova G.M. (2000), Kodzhaspirov A.Yu. Pedagogical dictionary: For students. higher and middle. ped. textbook routine. $\mathrm{M} \therefore$ Publishing Center "Academy", 176 p.

6. Sukhomlinskaya O.V. (2003), Historical and pedagogical process: new approaches to general problems. K .: A.P.N.,. $68 \mathrm{~s}$.

7. Ponomarev O.S. (2016), Axiology of education and the formation of the national elite. URL: http //: archive.kpi.kharkov. (appeal date: January 20, 2018).

8. Rozman I.I. Ukrainian pedagogical biography (second half of the XXbeginning of the XXI century): monograph. Uzhhorod: RIK-U, 2020. P.7.

Анотація. У статті розглядаються шляхи дослідження педагогічних персоналій. Особлива увага надається висвітленню значення методів вивчення досвіду вченого. Зазначено, щзо для детального дослідження педагогічної персоналії необхідно знати особливості життєвого історичного періоду вченого.

Ключові слова: педагогічна біографістика, діахронний метод, предмет дослідження.

Стаття відправлена: 22.10.2020

(C) Розман I.I. 